\title{
The Impact of Saudization on Saudi Women Consumers
}

\author{
Amal M. Alzahrani, Afaf O. Elhage and Ahlam Q. Alatawi \\ Department of Administrative Sciences, Community Collage, Tabuk University, \\ P.O. Box741, 71491 Tabuk, Saudi Arabia
}

\begin{abstract}
The need to reduce unemployment rate is a core responsibility of government and several countries are applying progressive initiatives to do so. Saudization is an example of such an initiative; Saudi Arabian policy introduced in 2003 to reduce percentage of unemployed Saudi nationals. The Ministry of Labour is exploring the possibility of Saudizing the vast retail sector, especially, commercial centres and malls as part of its efforts to find more areas to employ young Saudi including women. The purpose of this study is to investigate the impact of Saudization on Saudi women's attitudes to the retail sector (Saudizing shops from female customer's perspective). The literature review examines previous empirical studies on the context of Saudization in the retail shops, factors that affect Saudi women shopping experience as well as a theoretical framework in this context. Data for the study has been collected through a survey completed by 173 respondents. The results suggest that the presence of female workers minimize the feeling of embarrassment and creates a pleasurable shopping experience for Saudi female customers. The findings confirm that Saudizing shops has a significant impact on the shopping experience of Saudi women in the retail sector.
\end{abstract}

Key words: Saudization retail sector, ABC Model of attitudes, shopping experience, workers, Saudization

\section{INTRODUCTION}

During the last two decades, the private sector in the Kingdom of Saudi Arabia has suffered from several economic challenges and social difficulties, caused by the foreign labour (Ramady, 2005). Of these, the spread of unemployment among Saudi citizens has been one of the most significant concerns. Furthermore, Saudi government has been increasingly wary of over dependence on foreign labour, especially as the economy appears to be suffering from the high percentage of remittances that foreign labour transfer to their families in their home countries each year (Al-Sheikh, 2015). However, it was the growing unemployment rate among Saudis that prompted the government to introduce its saudization policy of jobs; the aforementioned "Saudization" (Rice, 2004). The policy of Saudization requires the replacement of expatriates with competent and skilled local employees wherever possible (Law et al., 2009).

Sohail (2015) affirms that the retail sector in the Saudi Arabia is rapidly changing the face of Saudi Arabia. According to Breckler (1994), attitude is composed of three components:

- Affective component involves the feelings, responses and emotions of the individual towards the issue of the attitude

- Behavioural component includes the intentions or the tendency of conduct or to act in a certain way about the subject of the attitude

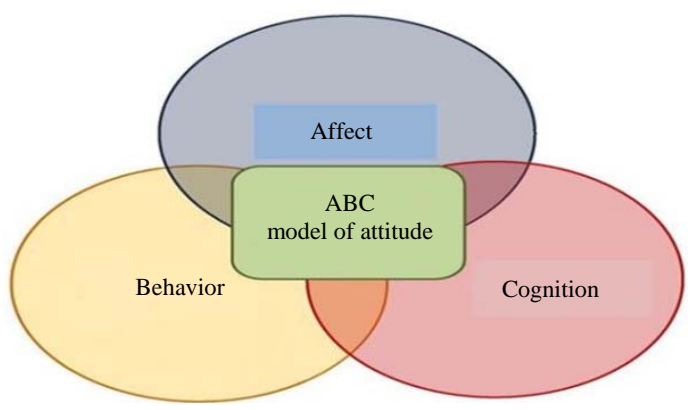

Fig. 1: ABC Model of attitude

- Cognitive component which comprises the beliefs about and ideas on the subject of the attitude. This model is known as the (ABC Model of attitudes) (Fig. 1)

In view of the ABC Model, the affective component refers to the emotional response an individual exhibits (disliking or liking) towards the attitude of the object. Therefore, one's attitude towards an object cannot be determined by simple identification of its beliefs. Agarwal and Malhotra (2005) note that the affect (emotions and feelings) and attitude research are joined to initiate a model of choice and attitude. The behavioural component is non-verbal or verbal tendency by an individual. It comprises of actions or responses (observable that is) which come up as a result of an

Corresponding Author: Amal M. Alzahrani, Department of Administrative Sciences, Community Collage, Tabuk University, P.O. Box 741, 71491 Tabuk, Saudi Arabia 
attitude object. It includes one's response to perform an act in relation to attitude object. These particular responses are more often bound to exhibit succinct predictability or organisational structure. The cognitive component refers to the thoughts and beliefs an individual has about the attitude object.

\section{MATERIALS AND METHODS}

Quantitative survey questionnaires were used to collect the necessary data to fulfil the aims of this study. The first step was to conduct a pilot study involving five participants only to complete the questionnaire. The aim of the pilot study was to collect feedback on the validity and usability of the questionnaires. The selection of a sample is an important stage in any research. Saunders et al. (2009) note that the sampling technique offers a range of methods that enable one to minimise the amount of data they need to collect by studying a portion of a larger population. Sampling techniques can be divided into two: probability and non-probability sampling. In probability sampling the chance of an item being selected is known and equal for all cases while in non-probability (random) sampling the probability of a case being selected is unknown (Saunders et al., 2009).

As the data was collected using quantitative research methods, quantitative data analysis tools were employed. Data from the survey questionnaires was analysed using the SPSS programme. This programme was selected for this study as it can handle large amounts of data and can perform the type of analysis needed for the study. This research was also based on secondary data collection mechanisms including information from relevant books, academic journals and databases.

\section{RESULTS AND DISCUSSION}

During the survey, 200 and 8 people selected to participate. A total number of 173 participants successfully completed the questionnaire representing the opinions and views of women in the Kingdom of Saudi Arabia concerning their shopping experiences and their attitude in Saudized shops, resulting in an $84 \%$ response rate. As showed in Fig. 2, about 93.06\% have been served in the shop by a female Saudi national.

As illustrated in Fig. 2 approximately 32.37\% of the women agreed that the service provided by female workers is different to the service provided by male workers, followed by neutral (31.21\%), strongly agree (30.06\%), disagree (4.05\%) and strongly disagree (2.31\%) as shown by figure. Very few respondents showed contrary opinion indicating that most women agree that the service provided by female workers is different to the service provided by male workers. Therefore, it is common knowledge that the service provided by female

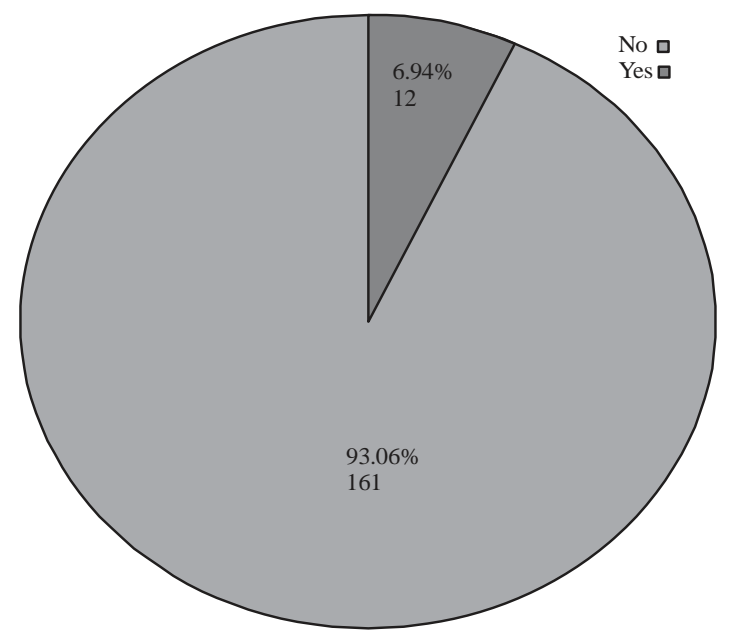

Fig. 2: Served by female Saudi national; Haveyou ever been served in a shop by a female Saudi national

sworkers is different from that of men and that of women workers has unique attraction to the female consumers.

According to female customer's attitude towards female workers, $10.4 \%$, equivalent to 18 respondents strongly agreed that female workers are more patient. $16.2 \%$ (28 respondents) just agreed. A good number, equivalent to $31.2 \%$ or 54 respondents showed neutrality on this matter while a majority (34.7\% of the respondents or 60 disagreed. Those who strongly disagreed were only $2.9 \%$. In general, women do not perceive that female workers are more patient than male workers. Probably, male workers are equally patient. On the other hand, there is a possibility that the neutrality indicated by some respondents can be interpreted that this phenomena is not perceived by consumers on either gender.

Majority of the participants were neutral (36.4\%) that female workers are better able to establish a relationship with their customers, followed by agreed (30.1\%), strongly agreed (17.3\%), disagreed (13.3\%) and strongly disagreed (2.9\%). Most of the women strongly agreed (52\%) that the presence of female workers in the shops minimises any feeling of embarrassment, followed by agreed (30.1\%), neutral (12.7\%), disagreed (2.9\%) and strongly disagreed (2.3\%). About $43.4 \%$ of the female participants were neutral that female workers are more able to handle customer's complaints, followed by disagreed (23.1\%), agreed (21.4\%), strongly agreed (9.8\%) and strongly disagreed (2.3\%). Approximately (35.26\%) of the participants were neutral that female workers are more persuasive, followed by agreed (31.79\%), strongly agreed (17.92\%), disagreed (13.87\%) and strongly disagreed (1.16\%) as shown by Table 1.

Majority of the participants agreed (45.09\%) that female workers understand their needs better, followed by 
Table 1: Female customer's attitude towards female workers

\begin{tabular}{|c|c|c|}
\hline Items & Frequency & Percent \\
\hline \multicolumn{3}{|c|}{ Female workers are more patient than men workers } \\
\hline Strongly disagree & 13 & 7.5 \\
\hline Disagree & 60 & 34.7 \\
\hline Neutral & 54 & 31.2 \\
\hline Agree & 28 & 16.2 \\
\hline Strongly agree & 18 & 10.4 \\
\hline \multicolumn{3}{|c|}{ Female workers are better able to establish a relationship with their customers } \\
\hline Strongly disagree & 5 & 2.9 \\
\hline Disagree & 23 & 13.3 \\
\hline Neutral & 63 & 36.4 \\
\hline Agree & 52 & 30.1 \\
\hline Strongly agree & 30 & 17.3 \\
\hline \multicolumn{3}{|c|}{ The presence of female workers in the shops minimises any feeling of embarrassment } \\
\hline Strongly disagree & 4 & 2.3 \\
\hline Disagree & 5 & 2.9 \\
\hline Neutral & 22 & 12.7 \\
\hline Agree & 52 & 30.1 \\
\hline Strongly agree & 90 & 52.0 \\
\hline \multicolumn{3}{|c|}{ Female workers are more able to handle customer's complaints } \\
\hline Strongly disagree & 4 & 2.3 \\
\hline Disagree & 40 & 23.1 \\
\hline Neutral & 75 & 43.4 \\
\hline Agree & 37 & 21.4 \\
\hline Strongly agree & 17 & 9.8 \\
\hline \multicolumn{3}{|c|}{ The female workers are more persuasive } \\
\hline Strongly disagree & 2 & 1.16 \\
\hline Disagree & 24 & 13.87 \\
\hline Neutral & 61 & 35.26 \\
\hline Agree & 55 & 31.79 \\
\hline Strongly agree & 31 & 17.92 \\
\hline Total & 173 & $100.0 \%$ \\
\hline
\end{tabular}

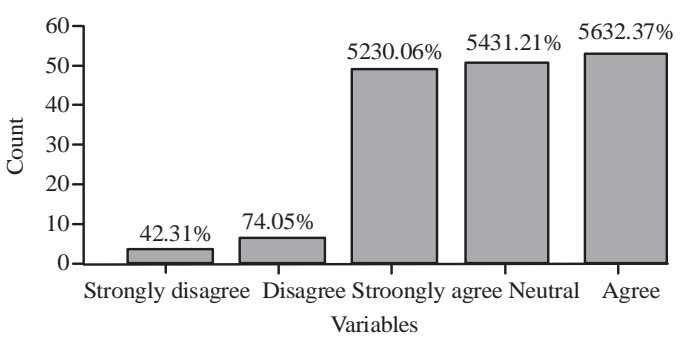

Fig. 3: Service provided by female workers; The service provided by female workers is different to the service provided by male workers

strongly agreed (34.68\%), neutral (16.18\%), disagreed (2.89\%) and strongly disagreed (1.16\%) as shown by Fig. 3. A small number of women do not agree that female workers better understand the needs of the female customers (2.89\% who disagreed and another $1.16 \%$ who strongly disagreed). This analysis shows that customer think that female workers better understand their needs. However, although the research suggests this it cannot be said that all men do not understand female shopper's needs Fig. 4.

The findings show that there is an impact of Saudization on Saudi women shopping experience in the retail sector. Saudization has led to an increase in the

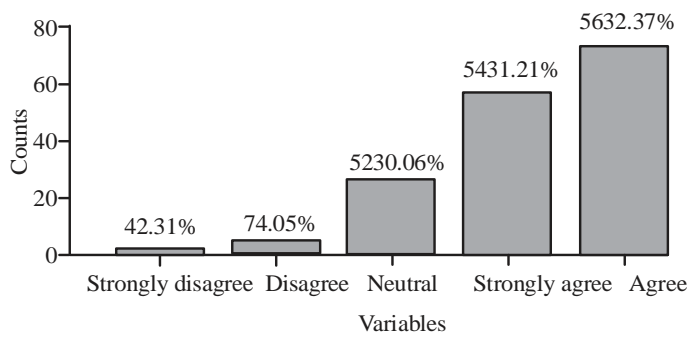

Fig. 4:Understanding needs; Female workers understanding my needs better

number of women workers in the retail shops who assist female customers in doing shopping. According to the research, most women customers attested to have been served by a female Saudi national, representing $92.86 \%$ of the sum total of the respondents. The large percentage of those who attested to have been served by Saudi female national is evidence of the increased number of Saudi women in the retail shops.

In essence, Saudi women feel that presence of female workers in the shops minimises the feeling of embarrassment. Owners of retail shops dealing in lingerie and make-up products thus need to consider having more female workers in the shops as opposed to male, so as to minimise the feeling of embarrassment. Shops with more 
female workers are likely to attract female customers as opposed to those that do not. In overall, Saudization has improved the shopping of experience of female consumers. Saudization has increased the number of women in Saudi shops. This implies that more women are attracted to the retail shops given that there are fellow women workers who are not only knowledgeable about make-up or technology products but also better in handling in handling customer's complaints. $27.75 \%$ of the respondents strongly agree that Saudization has changed the shopping experience. In addition, 32.95\% agree while $27.75 \%$ were just neutral. However, some respondents still believe that Saudization has not changed in any way, the female's shopping experience. This view was held by $6.9 \%$ of the respondents who disagreed and $4.62 \%$ who strongly disagreed.

\section{CONCLUSION}

The findings confirm that Saudization had a positive impact on the shopping experience of Saudi women customer's attitude in the retail sector in the kingdom of Saudi Arabia. Furthermore, the findings give light into key areas that future studies should focus on. For example, there is need to explore the opinions of male respondents about Saudization. It is believed that the findings of this study will provide rationale for improving the existing Saudization of retail shops in Saudi Arabia. As reflected in the research, Saudization has led to an increase in the number of Saudi female workers in the retail shops; consequently impacting on the Saudi women shopping experience.

\section{REFERENCES}

Agarwal, J. and N.K. Malhotra, 2005. An integrated model of attitude and affect: Theoretical foundation and an empirical investigation. J. Bus. Res., 58: 483-493.

Al-Sheikh, H.M., 2015. Current progress in the nationalisation programmes in Saudi Arabia. GLMM-Gulf Labour Markets and Migration, Centro de Politicas de Migracao, Florence, Italy. https://cadmus.eui.eu/handle/1814/34580

Breckler, S.J., 1994. A comparison of numerical indexes for measuring attitude ambivalence. Educ. Psychol. Meas., 54: 350-365.

Law, K.S., L.J. Song, C.S. Wong and D. Chen, 2009. The antecedents and consequences of successful localization. J. Int. Bus. Stud., 40: 1359-1373.

Ramady, M.A., 2005. The Saudi Arabian Economy: Policies, Achievements and Challenges. Springer, New York, USA., ISBN-13: 978-0387248332, Pages: 496.

Rice, G., 2004. Doing business in Saudi Arabia. Thunderbird Int. Bus. Rev., 46: 59-84.

Saunders, M., P. Lewis and A. Thornhill, 2009. Research Methods for Business Students. 5th Edn., Prentice Hall, Essex FT., ISBN: 9780273716860, Pages: 614.

Sohail, M.S., 2015. Gender differences in mall shopping: A study of shopping behaviour of an emerging nation. J. Marketing Consum. Behav. Emerging Markets, 1: 36-46. 